\title{
妊娠に伴った結核性頸部リンパ節炎例
}

\author{
加藤 崇 - 西池 季隆 - 長井 美樹 \\ 小西 雅樹・坂田 義治
}

\section{A Case of Cervical Tuberculous \\ Lymphadenitis with Pregnancy}

Takashi Kato, Suetaka Nishiike, Miki Nagai, Masaki Konishi and Yoshiharu Sakata

(Suita Municipal Hospital)

\begin{abstract}
Tuberculosis in Japan has increased recently. Cervical tuberculous lymphadenitis is an extrapulmonary tuberculosis. We report a case of a 29 -year-old woman who was 28 weeks pregnant, with cervical tuberculous lymphadenitis, which was diagnosed by tuberculin reaction and polymerase chain reaction test (PCR test) after delivery. The patient was treated with rifampicin (RFP), isoniazid (INH) and levofloxacin (LVFX) as antituberculous chemotherapy for a year, and was treated with INH and LVFX for the next half-year. The baby was treated with bacillus Calmette-Guerin vaccine (BCG vaccine) instead of antituberculous chemotherapy. The patient and the baby were making satisfactory progress. Although antituberculous chemotherapy should be done immediately when a pregnant woman is diagnosed with pulmonary tuberculosis, it should not be done immediately when the pregnant woman has cervical tuberculous lymphadenitis.
\end{abstract}

Key words : cervical tuberculous lymphadenitis, pregnancy, extrapulmonary tuberculosis, tuberculin reaction, PCR test

\section{はじめに}

戦後, 結核予防法の制定や治療効果の高い抗結核薬の 登場に伴い, 本邦にお括り結核罹患率は著しく低下し, 結核への関心も徐々に薄れていった。

しかし最近, 結核は再び増加傾向にあり, 本邦におけ る結核医療も, 患者の高齢化, 院内感染の多発, 集団感 染の増加, エイズとの合併, 発見の遅れ, 在日外国人の 結核多発など新しい局面を迎えていると考えられる1).

ところで, 妊娠に伴った結核いわゆる妊婦結核の頻度 は，欧米ではすでに増加傾向にあると報告されている2). 本邦でも約 5000 例に 1 例と非常にまれとされていた が 3), 最近, 国際交流の増加に伴い, 今後は増加する可 能性があると懸念されている ${ }^{4)}$. 妊婦が耳鼻咽喉科領域
の結核に罹患した場合, 耳鼻咽喉科医も妊婦結核の診断, 治療にかかわらなければならない. しかし, 母体, 胎児 に対する影響についても常に配慮しなければならず，判 断に苦渋することも少なくないと考えられる.

今回，われわれは耳鼻咽喉科領域の妊婦結核のなかで も結核性頸部リンパ節炎の 1 例を経験したので文献的考 察む加え報告する。

\section{症例}

患者 : 29 歳, 妊娠 28 週.

主訴：右側頸部無痛性腫瘤.

現病歴: 平成 12 年 7 月, 本人が右側頸部腫瘤に気付 く. その後, 放置していたが徐々に増大傾向を認めたた 
內, 8 月 9 日, 精查, 治療目的にて当院産婦人科より紹 介受診となった。 なお，娃娠経過浪好であった。

既往歷：特になし。

現症：耳鼻咽喉科領域に明らかな器質的病変を認めな かった. 右側頸部中央, 胸鎖乳突筋後縁に $4.5 \times 4.5 \mathrm{~cm}$ で暗赤色呈する表面不整, 比較的弾性軟, 可動性不良 の腫瘤を触知したが，ほかに明らかなリンパ節腫脹を触 知しなかった。

血液検查：WBC8100（Seg 82.3\%), CRP 0. $47 \mathrm{mg} / \mathrm{dl}$, と高值のほかに異常所見を認めなかった。

経過：8月 24 日, 頸部エコーにて充実性囊胞性腫瘤を 認めた（図 1).8月 28 日, 白色膿汁 $3 \mathrm{ml}$ を穿刺吸引し たが, 穿刺部位に瘦孔を形成し, 流注膿湯となった。膿 汁の細菌培養では菌体を認めず, 細胞診では好中球を多 数認めるものの明らかな亜性細胞を認めなかった. 10 月 16 日, 正常分婏にてアプガースコア 9 点の男児を出産. 10 月 30 日, 生検術を施行したが, チールニールセン染 色, PAS 染色にて菌体を認めなかった。11月 6 日, MRI にて充実性囊胞性腫瘤と両頸部に多数のリンパ節腫脹を 認めた（図 2A）。11月15 日，ツベルクリン反応（以下： ツ反）にて $6 \times 8 \mathrm{~cm}$ の強陽性, 流注膿瘍から採取した膿 汁で行った結核菌核酸同定検查（以下：PCR 検査）にて 陽性を認め, 胸部 X 線や他の耳鼻咽喉科領域に結核を疑 う病変を認めなかったので, 結核性頸部リンパ節炎と確

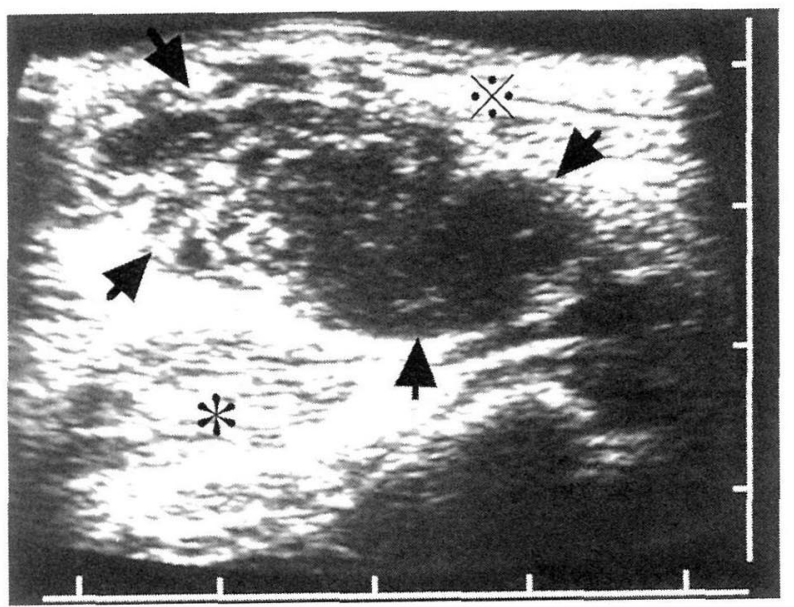

図 1 靧部エコー写真

$4.5 \times 3.0 \times 2.0 \mathrm{~cm}$ の充実性囊胞性腫瘤で，一部液体貯留 を認好 (矢印)。 皮下に存在し，筋層との境界も明膫である. *: 胸鎖乳突筋, ※: 皮膚および皮下組織
定診断した.

11 月 17 日, 呼吸器内科医との協議の上で授乳を一切 禁止し, リファンピシン（以下：RFP），イソニアジド (以下：INH)，レボフロキサシン（以下：LVFX）にて治 療を開始した。1 月28 日, 出生児のツ反が陰性だった ので，ただちに BCG 接種を行ったが抗結核薬の予防投 与は行わなかった。治療 2 週間後より腫瘤の縮小傾向を 認め, 1力月後, 初診時の約半分の大きさになったので (図 $3 \mathrm{~A}$ ), その後も定期的に血液検查や MRI 検查を施行 しながら治療を継続した。平成 13 年 10 月 24 日, 腫留の 瘷痕化を認めたが (図 $3 \mathrm{~B}$ )，MRI 検查にてリンパ節腫脹 の残存を認めたので（図 $2 \mathrm{~B}$ ), 呼吸器内科医との協議の 上でさらにINH，LVFX を継続投与した。平成 14 年 5 月 15 日, MRI 検査にて腫瘤はほぼ消失し, リンパ節腫脤の 残存も認めなかったので（図 $2 \mathrm{C}$ ), 呼吸器内科医との協 議の上で抗結核薬の投与を終了し経過観察とした. 11 月 27 日, MRI 検査にて変化を認めず，その後の経過観察に おいても血液検查や理学所見などに異常を認めていない (図 4).

\section{考 察}

本邦におけ結核罹患率は，年齢が上昇するにつれて 高くなっている. しかし, 年齢階級別登録者数では 20 29 歳代に突出がみられており ${ }^{5)}$, 女性にとって妊娠する 率が一番高い時期であることを考えると，本邦でも娃婦 結核の頻度が増加する可能性があると考えられる.

今回の症例は, 妊婦結核のなかでる結核性頸部リンパ 節炎であり, 分娩退院後に施行したツ反と PCR 検查によ り確定診断がついた。一般的に結核性頸部りンパ節炎は, 耳鼻咽喉科でも遭遇する機会の多い疾患であり, 多くは 片側無痛性腫瘤を呈し, 活動性肺病変を伴わないため, ほかの頸部リンパ節腫脹をきたす疾患群との鑑別が困難 であるとされている（表 1）6） 9). 今回，確定診断が遅 れた理由として, 妊娠後期であったこと, 自覚症状, 超 音波所見，穿刺細胞診より悪性疾患が否定されたこと， 悪性疾患が否定された時点で積極的に精查を進めずに分 婏を優先させたことが挙げられる。しかし，結核性頸部 リンパ節炎の場合, 生検術後に穿刺部や切開部から瘦孔 形成をきたす例もあると報告されており7)，やはり穿刺 後に腫瘤が治癒しなかった段階で, ツ反や PCR 検査など の精查を進めるべきであったと考えられる。

娃婦に対する薬剤投与は, 原則として控える方が良く, 

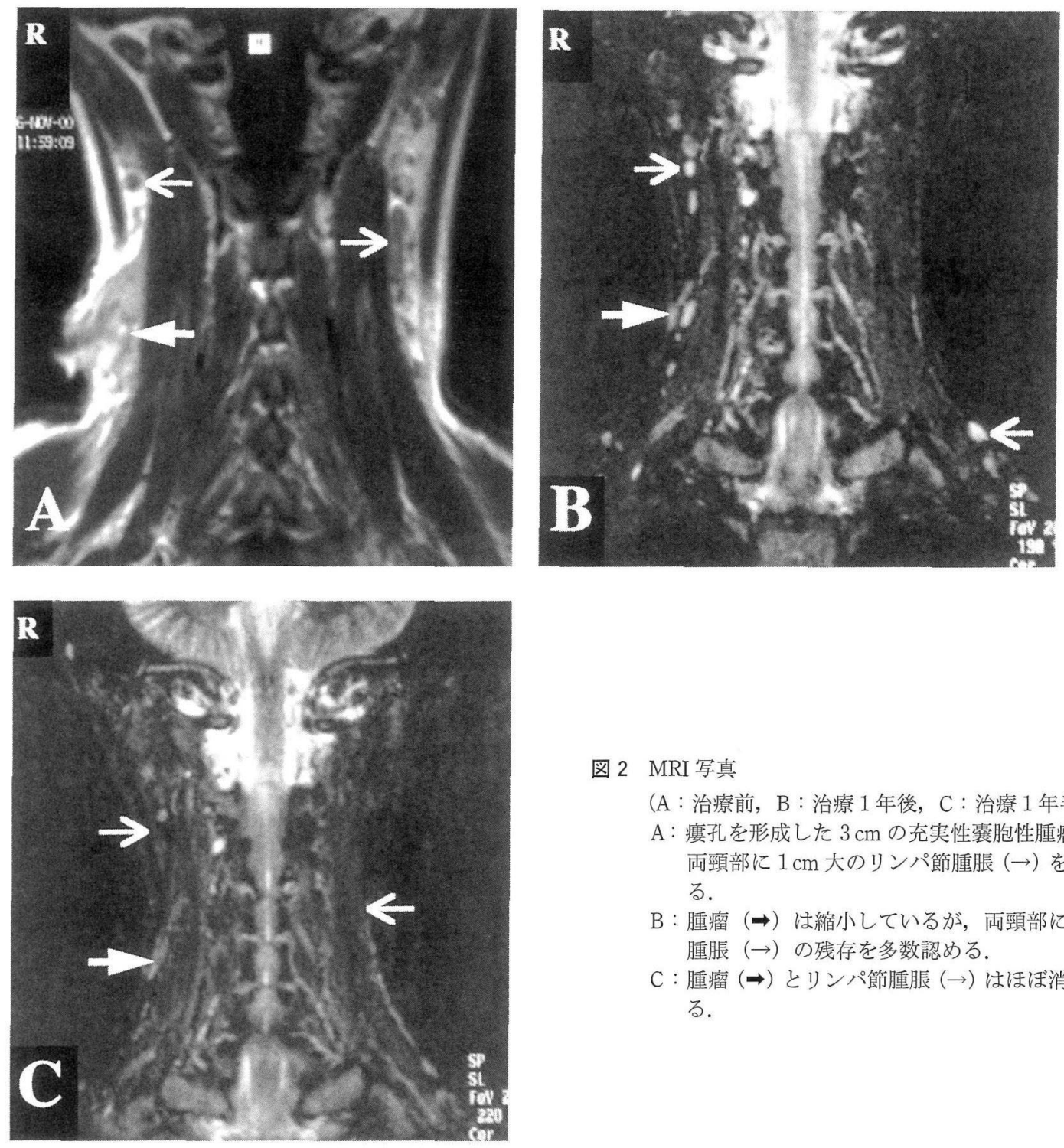

図 2 MRI 写真

（A：治療前, B : 治療 1 年後, C : 治療 1 年半後）

$\mathrm{A}$ ：瘻孔を形成した $3 \mathrm{~cm}$ の充実性囊胞性腫瘤（一）と 両頸部に $1 \mathrm{~cm}$ 大のリンパ節腫脹 $(\rightarrow)$ を多数認め る.

B：腫瘤（） は縮小しているが，両頸部にリンパ節 腫脹 $(\rightarrow)$ の残存を多数認める.

$\mathrm{C}$ : 腫瘤 $(\rightarrow)$ とリンパ節腫脹 $(\rightarrow)$ はほぼ消失してい る.

妊娠前に結核に罹患した場合，結核治療が終了するまで 妊娠を避けるべきである。しかし，妊娠中に結核に罹患 した場合, 母体, 胎児に詨する生命の危険性を伴うため 何らかの対応が必要になる。化学療法が確立する以前, 妊娠中毒症や不正性器出血などの合併が多く, 妊娠 16 28 週における流産率が高かったため, 娃娠中絶が勧めら れていた10111. しかし, 化学療法が確立した現在, これ らの異常は適切な治療が行われていれば一般妊婦におけ る率とほぼ同じとされており，逆に胎児先天性結核の可 能性や母児の転帰を考えると，妊娠中でも積極的に結核 治療を行うことが重要であるとされている12)～14)．なか には，妊娠中の結核治療は非妊娠時と同様に行うのが原
則であるという意見もある14).

本邦における妊婦結核の報告は，われわれが検索し 得た限り 10 例（肺結核 6 例, 肺・腸結核 1 例, 結核性胸 膜炎加ら産後に肺結核へ悪化したもの 1 例, 結核性胸膜 炎 1 例，結核性頸部リンパ節炎 1 例）であったが，その らち8例は確定診断直後より積極的治療を行ってお り，母児ともに経過良好であったと報告している（表 2) ${ }^{6144) ~}$ 18). しかし, 妊娠中は, 母体への副作用や胎児 への催奇形性の問題もあるため, 使用薬剤は慎重に選択 する必要があると考えられる12199.

現在，妊婦結核の初回標準治療は，本邦では INH，工 タンブトール（以下：EB）を主軸とし, 妊娠 4カ月以降 

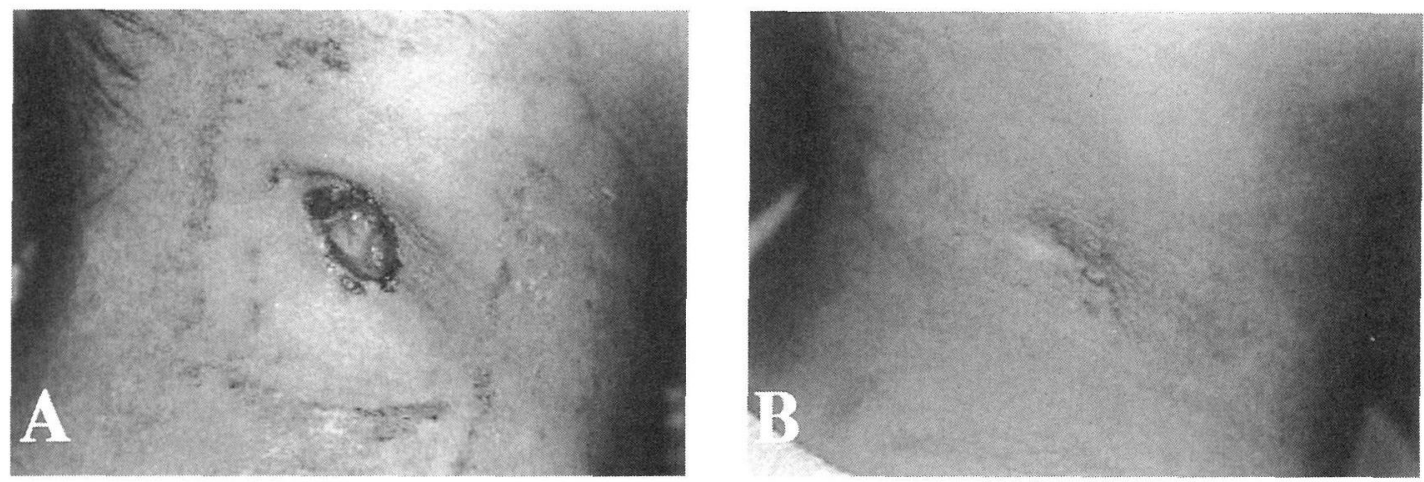

図 3 局所写真 $(A ：$ 治療 1 力月後, B：治療 1 年後)

$\mathrm{A}$ ：腫船は約半分に縮小しているが，肉芽の残存を認める。

$\mathrm{B}$ : 腫瘤の瘷痕化を認める.

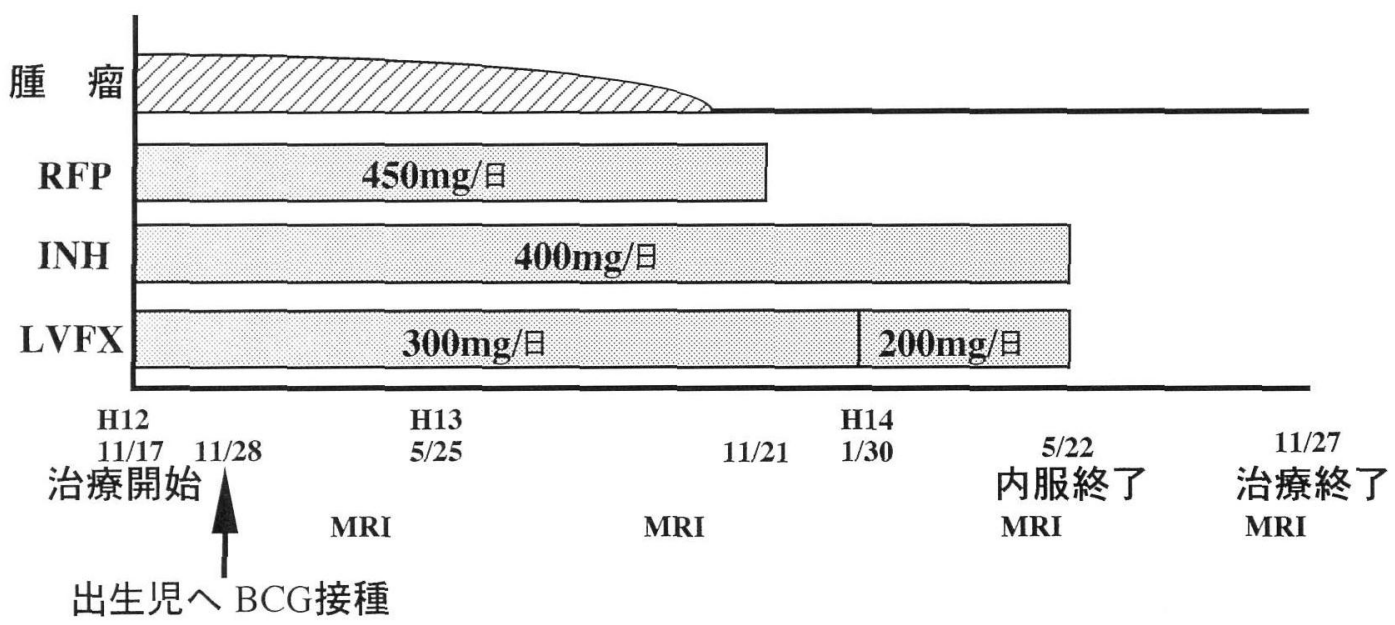

図 4 治療経過

なら RFP 投与も考慮するとされている12)。一方，欧米で は INH，RFP を第一選択とし，INH に耐性が認められた 場合や進行している場合に EB 投与む考慮するとされて いる ${ }^{20)}$ ．治療中の授乳は，母乳への移行性などより原則 的に禁止するといら意見321) と，必ずしも禁止する必要 がないといら意見4)12)13)15)17)22）の賛否両論があり，最近， 禁止する必要がないといら方向になっている。しかし， 定説が得られていないため, 結局, 個々の裁量に任せら れているのが現実である。

結核性頸部リンパ節炎の治療効果判定は，排菌量の減 少や院性化で判定することは不可能であり, 理学所見や 画像所見, 血液所見の改善などで判定せざるを得ないと 報告されているて). また，抗結核薬の投与期間について
大石ら ${ }^{8)}$ は，生検術後に残存リンパ節病変がないと判断 されても INH や RFPを $6 \sim 9$ カ月間投与し, リンパ節病 変の残存がある場合, その大きさを観察しつつ 9 12 月間投与すると報告しており，岩崎ら ${ }^{23)}$ は, リンパ節病 変の残存があった症例に15カ月間投与したと報告してい る.今回の症例も, 治療効果判定に理学所見や画像所見, 血液所見を用い, 定期的な MRI 検査でリンパ節病変の残 存を観察しながら, 呼吸器内科医との協議の上で抗結核 薬を16力月間投与した。

過去の妊婦結核における結核性頸部リンパ節炎の報告 は，海老澤ら ${ }^{6)}$ や Jana ら ${ }^{24)}$ が行っており，ともに妊娠 中より積極的に結核治療を開始し, 出生児にも INH 投与 を行い，合併症もなく母児ともに経過良好であったとい 
表 1 結核性頸部リンパ節炎について6) 9)

頻度：肺外結核症の約 30\%を占め，肺結核の合併は約 30\%である.

男性：女性=1:2 で, 右側頸部上方に無痛性腫瘤を呈することが多い.

病理組織 : ラングハンス型巨細胞, 類上皮細胞, 線維芽細胞, 乾酪壊死の出現. リンパ球, 形質細胞の浸潤.

病期 : 初期腫脹型 (特徵的な所見に乏しい), 浸潤型 (乾酪化を生じる), 膿瘍型（皮膚発赤を伴う), 潰瘍瘦孔型（炎症徴候 が強くなる), 硬化型 (発病後長期間経過しており炎症徵候は伴わない)

診断 : 問診 (既往歴や接触歴の有無など), 胸部 X 線, CT, 血液検查 (CRP 陽性や赤沈亢進など), ツベルクリン反応, 結核 菌の培養, 病理組織検査, PCR 検査など

鑑別診断：悪性リンパ腫, 悪性腫瘍リンパ節転移, 伝染性単核球症, 猫ひっかき病, 壊死性リンパ節炎, サルコイドーシス, 単純 性リンパ節炎など

治療：肺結核治療に準ずる。

肺結核合併例や瘦孔潰瘍形成で排菌が認められる例では入院治療も必要であるが，通常は外来通院治療で可能.

予後：良好

表 2 本邦における過去の妊婦結核の症例報告

\begin{tabular}{|c|c|c|c|c|c|c|c|c|}
\hline 症例 & 年齢 & 部位 & 週数 & 母体への治療 & 出生児への治療 & $\begin{array}{l}\text { アプガー } \\
\text { スコア }\end{array}$ & \multicolumn{2}{|c|}{ 報告 } \\
\hline 1 & 38 & 頸部リンパ節 & 13 & 19 週より INH, RFP, Vit B6 を投与. & 1 日目より INH を投与. & 9 & 海老澤ら6) & 1995 \\
\hline 2 & 30 & 肺 & 22 & $\begin{array}{l}22 \text { 週より INH, EB を投与. 出産後 } 5 \text { 週間 } \\
\text { のみ SM を追加. }\end{array}$ & $\begin{array}{l}8 \text { 日目より INH を投与. } \\
111 \text { 日目に BCG 接種. }\end{array}$ & & 佐道ら ${ }^{14)}$ & 1998 \\
\hline 3 & 36 & 胸膜・肺 & 26 & $\begin{array}{l}\text { 結核を疑うも抗結核薬を投与せず. 出産 } \\
\text { 1カ月より INH, RFP, SM を投与. }\end{array}$ & & 9 & 鈴鹿ら & 1999 \\
\hline 4 & 20 & 肺 & 24 & $\begin{array}{l}24 \text { 週より INH, RFP, EB を投与. } 2 \text { カ月 } \\
\text { 半後より INH, RFP を継続. }\end{array}$ & & 9 & & \\
\hline 5 & 29 & 肺 & 14 & $\begin{array}{l}14 \text { 週より INH, RFP を投与するが, } 16 \text { 週 } \\
\text { に患者希望で人工妊娠中絶を施行. }\end{array}$ & & & & \\
\hline 6 & 27 & 肺・腸 & 23 & $\begin{array}{l}23 \text { 週より INH, RFP, EB を投与. 産䙏後 } \\
\text { より SM を追加. }\end{array}$ & 1 日目より INH を投与. & 8 & 井畑ら ${ }^{16)}$ & 2000 \\
\hline 7 & 31 & 胸膜 & 32 & 35 週より INH，RFP，EB を投与. & 1 日目より INH を投与. & 8 & & \\
\hline 8 & 32 & 肺 & 29 & $\begin{array}{l}29 \text { 週より INH, EB を投与. 産褯後より } \\
\text { RFP, PZA を追加. }\end{array}$ & 1 日目より INH を投与. & 9 & & \\
\hline 9 & 24 & 肺 & 17 & $\begin{array}{l}17 \text { 週より INH，EB，PZA を投与. } 19 \text { 週よ } \\
\text { り INH, EB のみ継続投与. }\end{array}$ & INH を投与. & 9 & 坂井ら ${ }^{17)}$ & 2001 \\
\hline 10 & 29 & 肺 & 37 & 緊急帝王切開後に専門病院へ転院. & & 9 & 東矢ら ${ }^{18)}$ & 2001 \\
\hline
\end{tabular}

$\mathrm{SM}$ ：ストレプトマイシン PZA：ピラジンアミド Vit B6：ビタミン B6 空白：記載なし

うものであった. ところで，今回の症例は確定診断が遅 れ，退院後外来通院で結核治療を開始し，出生児には感 染性がそしいと考え抗結核薬の予防投与を行わなかった が，結果的に母児ともに経過良好であった。

活動性肺結核の場合, 感染性や生命の危険性より, た とえ妊娠中でも確定診断がつけば積極的に結核治療を開 始する必要がある. しかし, 結核性頸部リンパ節炎の場 合, 一般的に排菌状態や活動性肺結核を合併しているこ とが少なく，予後良好で感染性や生命の危険性がきわめ て低いと考えられるため6) 9), 妊娠後期で明らかな活動
性肺結核の合併や排菌を認めない場合，抗結核薬投与に よる副作用の可能性も考えると, 産婦人科医や呼吸器内 科医との協議の上で妊娠を優先させ, 出産後に結核治療 を開始してもよいのではないかと考えられる.

最後に, ニューキノロン薬が新しい抗結核薬として注 目されている. 今回の症例も呼吸器内科医の提言でLVFX を併用投与したが, 現在, ニューキノロン薬は初回治療 や単独投与を避け，既存の抗結核薬が副作用や耐性など で使用できない症例に対し投与するのが望ましいとされ ており ${ }^{25)}$, 今回の使用が適切であったかどうかは不明で 
ある. 今後, ニューキノロン薬の投与については, 検討 する余地があると考えられる.

以上, 妊娠に伴った結核性頸部リンパ節炎の症例を報 告したが，今回，精查が消極的になり，確定診断が遅れ たことは反省点である．最近の動向より，結核の可能性 も高く, 今後, 妊婦でも可能な限り積極的に精査を進め るべきであると考えられる，また，結核性頸部リンパ節 炎の場合, 感染性や生命の危険性がきわめて低いため, 母体の妊娠週数にもよるが，全例すぐに治療を開始する 必要はないのではないかと考えられる.

\section{まとめ}

1. 妊娠 28 週の結核性頸部リンパ節炎の 1 例を報告し た.

2. 出産後に行ったツ反と PCR 検查で確定診断し, 治 療は外来通院で行った。

3. 母体に対しては授乳を禁止し, 抗結核薬を 1 年半投 与したが，出生児に対しては BCG 接種のみ行った。

4. 効果判定は理学所見, 血液所見, MRI 所見を用い, 母児ともに経過良好であった。

5. 妊娠後期で結核性頸部リンパ節炎の場合, 確定診断 後すぐに治療を開始しなくても良いのではないかと考え られた。

本論文の要旨は, 第 284 回日本耳鼻咽喉科学会大阪地方連合 会 (平成 15 年 3 月 1 日, 大阪市), 第 65 回耳鼻咽喉科臨床学会 （平成 15 年 7 月 4 日， 5 日，京都市）において口演した.

\section{参考文献}

1）厚生省保健医療局エイズ結核感染症課：結核の統計 1998. 結核予防会, 1998.

2) Vallejo JG and Starke JR : Tuberculosis and pregnancy. Clin Chest Med $13: 693 \sim 707,1992$.

3）柳沼 忞: 妊娠，産褯に打ける抗結核薬. 結核 $62: 680 \sim$ 684, 1987.

4）古橋信晃：最近の妊婦における結核について。産婦人科治 療 $79: 568 \sim 572,1999$.

5）厚生統計協会：結核。国民衛生の動向（厚生の指標臨時増 刊）: $159 \sim 164,1998$.

6) 海老澤寛, 藤井浩一, 竹内 崇, 他 : 肺外結核合併妊娠の 一例. 日産婦東京会誌 $44: 264 \sim 268,1995$.

7）谷澤 誠, 田野正夫：リンパ節結核. CURRENT THERAPY $18: 131 \sim 134,2000$.

8）大石公子, 瓶飼幸太郎, 坂倉康夫, 他：当教室 12 年間の頸
部リンパ節結核の臨床統計的観察.耳鼻臨床 $79: 609$ 〜 616, 1986.

9）石塚洋一：耳鼻咽喉科領域の結核症。耳鼻臨床 $92 ： 326 \sim$ 327, 1999.

10) Snider D : Pregnancy and tuberculosis. Chest $86: 10 S \sim 13 S$, 1984.

11) Bjerkedal T, Bahna SL and Lehmann EH : Course and outcome of pregnancy in women with pulmonary tuberculosis. Scand J Respir Dis $56: 245 \sim 250,1975$.

12）渡辺 彰：産婦人科感染症のすべて一結核一, 産と婦 67 : $1589 \sim 1594,2000$.

13）森島祐子, 関沢清久 : 妊娠中の肺の生理と肺疾患一妊娠中 の結核一. 産婦人科の世界 $53: 61 \sim 66,2001$.

14）佐道俊幸, 山崎峰夫, 安川久吉, 他: 妊娠に合併した活動 性肺結核の 1 例. 産婦人科の進歩 $50: 474 \sim 477,1998$.

15）鈴鹿清美, 関谷宗英：産科加らた周産期感染症一妊婦と 結核一. 周産期医学 (増刊号) $29: 54 \sim 59,1999$.

16）井畑 欀, 遠藤方哉, 服部桂子, 他: 結核合併妊娠の 3 例. 日産婦神奈川会誌 $36: 62 \sim 66,2000$.

17）坂井啓造, 稲垣博英, 安永耕介, 他: 活動性肺結核合併妊 娠の 1 例. 産と婦 $68: 537 \sim 541,2001$.

18）東矢俊光, 岩政 仁, 鏡 輝雄：妊娠 37 週に喀血し結核と 診断された 1 症例. 日産婦熊本会誌 $45: 29 \sim 31,2001$.

19) Snider DE Jr, Layde PM, Johnson MW, et al. : Treatment of tuberculosis during pregnancy. Am Rev Respir Dis $122: 65 \sim$ 79, 1980.

20) Bass JB Jr, Farer LS, Hopewell PC, et al. : Treatment of tuberculosis and tuberculosis infection in adults and children; American Thoracic Society and The Centers for Disease Control and Prevention. Am J Respir Crit Care Med $149: 1359 \sim 1374$, 1994.

21）高杉知明, 川城丈夫：母体一の抗菌薬療法の指針 薬剤の 選択と治療の実際一結核. 周産期医学 $22: 1455 \sim 1457$, 1998.

22) American Academy of Pediatrics Committee on Drugs : The transfer of drugs and chemicals into human milk. Pediatrics $93: 137 \sim 150,1994$.

23）岩崎聖雄, 伊藤八次, 水田啓介, 他：頸部結核性リンパ節 炎の 6 例. 日耳鼻感染誌 $15: 100 \sim 104,1997$.

24) Jana N, Vasishta K, Saha SC, et al. : Obstetrical outcomes among women with extrapulmonary tuberculosis. $\mathrm{N}$ Engl $\mathrm{J}$ Med 341 : $645 \sim 649,1999$.

25）河原 伸, 多田敦彦, 永礼 旬：抗結核薬としてのニュー キノロン薬の臨床的評価. 結核 $74: 71 \sim 75,1999$.

原稿受付 : 平成15年 8 月 21 日 原稿採択：平成15年10月 8 日 別刷請求先 : 加藤 崇 テ564-0082 吹田市片山町2-13-20 市立吹田市民病院耳鼻咽喉科 